\title{
Synthesis, Characterization, X-Ray Crystal Structures and Antibacterial Activities of Oxidovanadium(V) Complexes with Hydrazone and Hydroxamate Ligands
}

\author{
Heng-Yu Qian \\ Key Laboratory of Surface \& Interface Science of Henan, School of Material \& Chemical Engineering, \\ Zhengzhou University of Light Industry, Zhengzhou, 450002 P.R. China \\ *Corresponding author: E-mail: hengyu_qian@126.com
}

Received: 05-07-2019

\begin{abstract}
Two new oxidovanadium $(\mathrm{V})$ complexes, $\left[\mathrm{VOL}^{1} \mathrm{~L}\right](\mathbf{1})$ and $\left[\mathrm{VOL}^{2} \mathrm{~L}\right] \cdot \mathrm{CH}_{3} \mathrm{OH}\left(2 \cdot \mathrm{CH}_{3} \mathrm{OH}\right)$, where $\mathrm{L}^{1}$ and $\mathrm{L}^{2}$ are the dianionic form of $N^{\prime}$-(3-bromo-2-hydroxybenzylidene)picolinohydrazide $\left(\mathrm{H}_{2} \mathrm{~L}^{1}\right)$ and 2-chloro- $N^{\prime}$-(2-hydroxy-3-methoxybenzylidene)benzohydrazide $\left(\mathrm{H}_{2} \mathrm{~L}^{2}\right)$, respectively, and $\mathrm{L}$ is the monoanionic form of 2-hydroxybenzohydroxamic acid $(\mathrm{HL})$, were prepared and characterized by elemental analysis, infrared and electronic spectroscopy. Structures of the complexes were further confirmed by single crystal $\mathrm{X}$-ray determination. The $\mathrm{V}$ atoms in the complexes are in octahedral coordination. The hydrazone ligands coordinate to the $\mathrm{V}$ atoms through the phenolate $\mathrm{O}$, imino $\mathrm{N}$, and enolate $\mathrm{O}$ atoms. The hydroxamate ligand coordinates to the $\mathrm{V}$ atom through the carbonyl and hydroxy $\mathrm{O}$ atoms. The complexes show effective antibacterial activity against $B$. subtilis, $S$. aureus and $E$. coli. The presence of $\mathrm{Cl}$ substitute group in the complex may enhance the antibacterial activity.
\end{abstract}

Keywords: Hydrazone; hydroxamate; oxidovanadium complex; crystal structure; antibacterial activity

\section{Introduction}

Schiff bases and their metal complexes have received considerable interest in coordination, catalytic, biological and medicinal chemistry. ${ }^{1}$ Vanadium acts as essential role in humans and many living organisms. The biological and pharmacological effects of vanadium element include coordination capability and chemical similarity between vanadate and phosphate. ${ }^{2}$ Some inorganic vanadates show insulin-mimetic properties, as well as antitumor activities. A number of vanadium complexes with various types of organic ligands are reported to possess interesting antidiabetic activity. ${ }^{3}$ In pursuit of new vanadium compounds with decreased toxic side effects and enhanced bioavail- ability, a great number of organic ligands and vanadium complexes have been investigated. ${ }^{4}$ The metal complexes of vanadium have the ability to normalize blood glucose level, thus, they can act as models of the haloperoxidases. ${ }^{5}$ Moreover, the metal complexes of vanadium possess interesting antimicrobial activities. ${ }^{6}$ In recent years, much attention has been focused on the biological properties of vanadium complexes. ${ }^{7}$ Some metal complexes of vanadium with hydrazone ligands have been reported for their antibacterial activities by our research group. ${ }^{8}$ In pursuit of new vanadium-based biocidal agents, we report here two new vanadium $(\mathrm{V})$ complexes, $\left[\mathrm{VOL}^{1} \mathrm{~L}\right](\mathbf{1})$ and $\left[\mathrm{VOL}^{2} \mathrm{~L}\right]$. $\mathrm{CH}_{3} \mathrm{OH}\left(2 \cdot \mathrm{CH}_{3} \mathrm{OH}\right)$, with the hydrazone ligands $N^{\prime}$-(3-bromo-2-hydroxybenzylidene)picolinohydrazide<smiles>O=C(N/N=C/c1cccc(Br)c1O)c1ccccn1</smiles>

$\mathrm{H}_{2} \mathrm{~L}^{1}$<smiles>COc1cccc(/C=N/NC(=O)c2ccccc2Cl)c1O</smiles>

$\mathrm{H}_{2} \mathrm{~L}^{2}$<smiles>O=C(NO)c1ccccc1O</smiles>

HL 
$\left(\mathrm{H}_{2} \mathrm{~L}^{1}\right)$ and 2-chloro- $N^{\prime}$-(2-hydroxy-3-methoxybenzylidene)benzohydrazide $\left(\mathrm{H}_{2} \mathrm{~L}^{2}\right)$, and 2-hydroxybenzohydroxamic acid (HL).

\section{Experimental}

\section{1. Materials and Measurements}

3-Bromo-2-hydroxybenzaldehyde, 2-hydroxy-3-methoxybenzaldehyde, picolinohydrazide and 2-chlorobenzohydrazide were purchased from Aldrich and used as obtained. Other solvents and reagents were made in China and used as received. $\mathrm{C}, \mathrm{H}$ and $\mathrm{N}$ elemental analyses were performed with a Perkin-Elmer 240 elemental analyzer. Infrared spectra were recorded on a Nicolet AVATAR 360 spectrometer as $\mathrm{KBr}$ pellets in the $4000-400 \mathrm{~cm}^{-1}$ region. UVVis spectra were recorded on a Lambda 900 spectrometer.

\section{2. Synthesis of Complex 1}

3-Bromo-2-hydroxybenzaldehyde $(0.10 \mathrm{mmol}, 20.0$ $\mathrm{mg})$ and picolinohydrazide $(0.10 \mathrm{mmol}, 13.7 \mathrm{mg})$ were dissolved in ethanol $(15 \mathrm{~mL})$. Mixture was stirred at room temperature for $30 \mathrm{~min}$ to give a colorless solution. To the solution an ethanolic solution $(10 \mathrm{~mL})$ of $\mathrm{VO}(\mathrm{acac})_{2}(0.10$ $\mathrm{mmol}, 26.5 \mathrm{mg}$ ) and 2-hydroxybenzoic acid $(0.10 \mathrm{mmol}$, $15.3 \mathrm{mg}$ ) was added with stirring. Mixture was further stirred at room temperature for $30 \mathrm{~min}$ to give deep brown solution. After keeping the solution in air for a few days, brown block-shaped single crystals, suitable for X-ray crystal structure determination were obtained. The crystals were isolated by filtration and dried in a vacuum des- iccator containing anhydrous $\mathrm{CaCl}_{2}$. Yield 33\% (177 mg). IR data $\left(\mathrm{KBr} ; v_{\max }, \mathrm{cm}^{-1}\right): 3453,3272,1607,953$. UV-Vis data in ethanol $\left(\lambda, \mathrm{nm}\left(\varepsilon, \mathrm{M}^{-1} \mathrm{~cm}^{-1}\right)\right]: 275(18,200), 305$ $(17,325), 326$ (16,312), 402 (4,535), 580 (1,105). Anal. Calcd. for $\mathrm{C}_{20} \mathrm{H}_{14} \mathrm{BrN}_{4} \mathrm{O}_{6} \mathrm{~V}(\%)$ : C, 44.72; H, 2.63; N, 10.43 . Found (\%): C, 44.60; H, 2.75; N, 10.32 .

\section{3. Synthesis of Complex 2}

3-Bromo-2-hydroxybenzaldehyde $(0.10 \mathrm{mmol}, 20.0$ $\mathrm{mg})$ and 2-chlorobenzohydrazide $(0.10 \mathrm{mmol}, 17.0 \mathrm{mg})$ were dissolved in ethanol $(15 \mathrm{~mL})$. Mixture was stirred at room temperature for $30 \mathrm{~min}$ to give a colorless solution. To the solution an ethanolic solution $(10 \mathrm{~mL})$ of $\mathrm{VO}(\mathrm{acac})_{2}$ $(0.10 \mathrm{mmol}, 26.5 \mathrm{mg})$ and 2-hydroxybenzoic acid $(0.10$ $\mathrm{mmol}, 15.3 \mathrm{mg}$ ) was added with stirring. Mixture was further stirred at room temperature for $30 \mathrm{~min}$ to give deep brown solution. After keeping the solution in air for a few days, brown block-shaped single crystals, suitable for $\mathrm{X}$-ray crystal structure determination were obtained. The crystals were isolated by filtration and dried in a vacuum desiccator containing anhydrous $\mathrm{CaCl}_{2}$. Yield 41\% (227 $\mathrm{mg})$. IR data $\left(\mathrm{KBr} ; v_{\max }, \mathrm{cm}^{-1}\right): 3465,3252,1618,953$. UVVis data in ethanol $\left(\lambda, \mathrm{nm}\left(\varepsilon, \mathrm{M}^{-1} \mathrm{~cm}^{-1}\right)\right]: 272(19,530), 290$ $(18,620), 335$ (9,755), 420 (1,272), 570 (1,533). Anal. Calcd. for $\mathrm{C}_{23} \mathrm{H}_{21} \mathrm{ClN}_{3} \mathrm{O}_{8} \mathrm{~V}$ (\%): C, 49.88; H, 3.82; N, 7.59. Found (\%): C, 50.12; H, 3.97; N, 7.45.

\section{4. X-ray Crystallography}

Diffraction intensities for the complexes were collected at 298(2) K using a Bruker D8 VENTURE PHOTON dif-

Table 1. Crystallographic data and refinement parameters for complexes $\mathbf{1}$ and $\mathbf{2} \cdot \mathrm{CH}_{3} \mathrm{OH}$

\begin{tabular}{|c|c|c|}
\hline Parameters & 1 & $2 \cdot \mathrm{CH}_{3} \mathrm{OH}$ \\
\hline Molecular formula & $\mathrm{C}_{20} \mathrm{H}_{14} \mathrm{BrN}_{4} \mathrm{O}_{6} \mathrm{~V}$ & ${ }_{23} \mathrm{H}_{21} \mathrm{ClN}_{3} \mathrm{O}_{8} \mathrm{~V}$ \\
\hline$M r$ & 537.20 & 553.82 \\
\hline Crystal color, habit & Brown, block & Brown, block \\
\hline Crystal system & Monoclinic & Monoclinic \\
\hline Space group & $P 2_{1} / c$ & $P 2_{1} / c$ \\
\hline$a, \AA$ & $10.811(1)$ & $11.972(1)$ \\
\hline$b, \AA$ & $17.282(1)$ & $9.583(1)$ \\
\hline$c, \AA$ & $12.535(1)$ & $21.101(1)$ \\
\hline$\beta, o$ & $95.810(1)$ & $103.792(1)$ \\
\hline$V, \AA^{3}$ & $2330.0(3)$ & 2351.1(3) \\
\hline$Z$ & 4 & 4 \\
\hline$\rho_{\text {calcd }}, \mathrm{g} \mathrm{cm}^{-3}$ & 1.531 & 1.565 \\
\hline$\mu, \mathrm{mm}^{-1}$ & 2.182 & 0.591 \\
\hline$F(000)$ & 1072 & 1136 \\
\hline Number of unique data & 4028 & 4378 \\
\hline Number of observed data $(I>2 \sigma(I))$ & 3038 & 3261 \\
\hline Independent parameters & 293 & 332 \\
\hline Restraints & 1 & 1 \\
\hline$R_{1}, w R_{2}(I>2 \sigma(I))$ & $0.0664,0.1683$ & $0.0568,0.1581$ \\
\hline$R_{1}, w R_{2}$ (all data) & $0.0899,0.1838$ & $0.0802,0.1731$ \\
\hline Goodness of fit on $F^{2}$ & 1.040 & 1.066 \\
\hline
\end{tabular}


fractometer with MoK $\alpha$ radiation $(\lambda=0.71073 \AA)$. The collected data were reduced using SAINT, ${ }^{9}$ and multi-scan absorption corrections were performed using SADABS. ${ }^{10}$ Structures of the complexes were solved by direct methods and refined against $F^{2}$ by full-matrix least-squares methods using SHELXTL. ${ }^{11}$ All of the non-hydrogen atoms were refined anisotropically. The amino $\mathrm{H}$ atoms were located from different Fourier maps and refined isotropically, with $\mathrm{N}-\mathrm{H}$ distances restrained to $0.90(1) \AA$. The other hydrogen atoms in both compounds were placed in idealized positions and constrained to ride on their parent atoms. Crystallographic data for the complexes are summarized in Table 1.

\section{5. Antibacterial Assay}

The antibacterial activity of the complexes was tested against $B$. subtilis, $S$. aureus, E. coli, and $P$. aeruginosa using LB medium (Luria-Bertani medium: Tryptone $10 \mathrm{~g}$, Yeast extract $5 \mathrm{~g}, \mathrm{NaCl} 10 \mathrm{~g}$, distilled water $1000 \mathrm{~mL}, \mathrm{pH}$ 7.4). The $\mathrm{IC}_{50}$ (half inhibitory concentration) of the test compounds were determined by a colorimetric method using the dye MTT (3-(4,5-di-methylthiazol-2-yl)-2,5-diphenyltetrazolium bromide).

A stock solution of the synthesized compound (1000 $\left.\mu \mathrm{g} \mathrm{mL}^{-1}\right)$ in DMSO was prepared and graded quantities of the test compounds were incorporated in specified quantity of sterilized liquid LB medium. Suspension of the microorganism was prepared and applied to 96-well assay plate with serially diluted compounds to be tested. $10 \mu \mathrm{L}$ of tested samples at pre-set concentrations were added to wells with penicillin as a positive reference and with the solvent control ( $5 \% \mathrm{DMSO})$ in medium and incubated at $37^{\circ} \mathrm{C}$ for $24 \mathrm{~h}$.
After $24 \mathrm{~h}$ exposure, $10 \mu \mathrm{L}$ of PBS (phosphate buffered saline $0.01 \mathrm{~mol} \mathrm{~L}^{-1}$, $\mathrm{pH} 7.4$ ) containing $4 \mathrm{mg} \mathrm{mL}^{-1}$ of MTT was added to each well. After $4 \mathrm{~h}$, the medium was replaced by $150 \mu \mathrm{L}$ DMSO to dissolve the complexes. The absorbance at $492 \mathrm{~nm}$ of each well was measured with an ELISA plate reader. The $\mathrm{IC}_{50}$ value was defined as the concentration at which $50 \%$ of the bacterial strain could survive.

\section{Results and Discussion}

\section{1. Chemistry}

The hydrazone ligands $\mathrm{H}_{2} \mathrm{~L}^{1}$ and $\mathrm{H}_{2} \mathrm{~L}^{2}$ were prepared by the reactions of 3-bromo-2-hydroxybenzaldehyde with picolinohydrazide, and 2-hydroxy-3-methoxybenzaldehyde with 2-chlorobenzohydrazide, respectively in ethanol. The two complexes were prepared by the reaction of the hydrazone ligands with $\mathrm{VO}(\mathrm{acac})_{2}$ and 2-hydroxybenzohydroxamic acid in ethanol (Scheme 1). Crystals of the complexes are soluble in DMF, DMSO, methanol, ethanol, and acetonitrile.

\section{2. Structure Description of the Complexes}

Molecular structures of complexes $\mathbf{1}$ and $\mathbf{2}$ are shown in Figs. 1 and 2, respectively. Selected bond lengths and angles are given in Table 2. The $\mathrm{V}$ atoms are in octahedral coordination, with the phenolate $\mathrm{O}$, imino $\mathrm{N}$ and enalate $\mathrm{O}$ atoms of the hydrazone ligands, and the hydroxy $\mathrm{O}$ atom of 2-hydroxybenzohydroxamate ligand defining the equatorial plane, and with the oxido $\mathrm{O}$ atom and the carbonyl $\mathrm{O}$ atom of the 2-hydroxybenzohydroxamate ligand<smiles>O=C(N/N=C/c1cccc(Br)c1O)c1ccccn1</smiles>

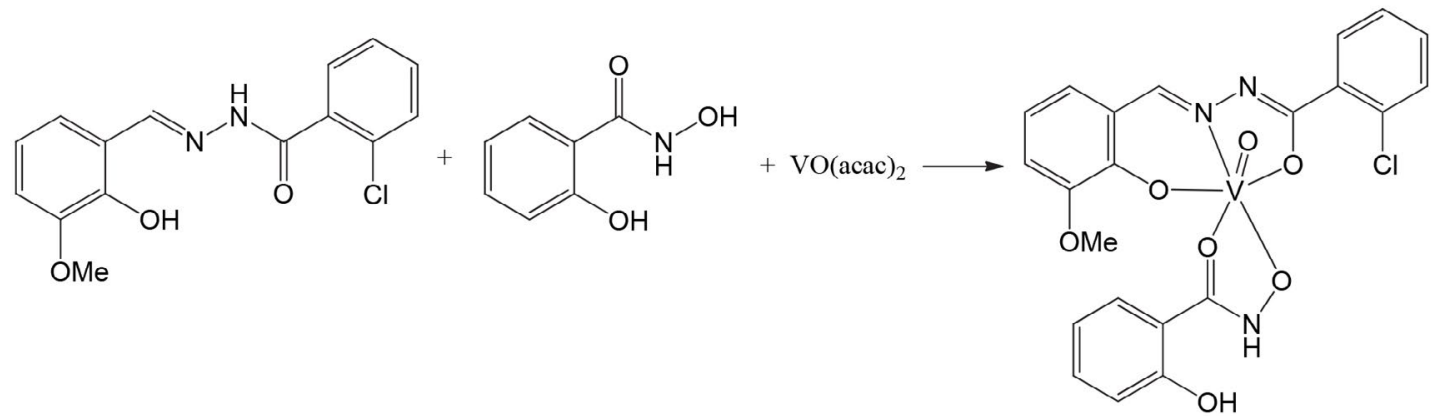

Scheme 1. The synthetic method of the complexes. 
locating at the axial positions. The $\mathrm{V}$ atoms deviate from the least-squares planes defined by the corresponding equatorial atoms by $0.265(1) \AA$ for $\mathbf{1}$ and $0.277(1) \AA$ for $\mathbf{2}$. The coordinate bond lengths in the complexes are comparable to each other, and similar to those observed in vanadium complexes with hydrazone ligands. ${ }^{12}$ The distortion of the octahedral coordination can be observed from the coordinate bond angles, ranging from $75.01(15)^{\circ}$ to $103.70(16)^{\circ}(1)$, and $74.98(11)^{\circ}$ to $103.59(13)^{\circ}(2)$, for the perpendicular angles, and from $154.74(16)^{\circ}$ to $170.84(17)^{\circ}$ for (1), and from $157.06(11)^{\circ}$ to $170.22(13)^{\circ}(2)$, for the diagonal angles. The dihedral angles between the two aromatic rings of the hydrazone ligands are $7.2(5)^{\circ}$ for $\mathbf{1}$ and

Table 2. Selected bond distances $(\AA)$ and angles $\left({ }^{\circ}\right)$ for complexes 1 and $2 \cdot \mathrm{CH}_{3} \mathrm{OH}$

\begin{tabular}{|c|c|c|c|}
\hline \multicolumn{4}{|c|}{1} \\
\hline $\mathrm{V} 1-\mathrm{O} 1$ & $1.878(4)$ & $\mathrm{V} 1-\mathrm{O} 2$ & $1.959(4)$ \\
\hline $\mathrm{V} 1-\mathrm{O} 3$ & $1.854(3)$ & $\mathrm{V} 1-\mathrm{O} 4$ & $2.217(4)$ \\
\hline V1-O6 & $1.588(4)$ & V1-N1 & $2.072(4)$ \\
\hline O6-V1-O3 & $95.90(18)$ & O6-V1-O1 & $100.01(19)$ \\
\hline $\mathrm{O} 3-\mathrm{V} 1-\mathrm{O} 1$ & $103.70(16)$ & $\mathrm{O} 6-\mathrm{V} 1-\mathrm{O} 2$ & $97.29(18)$ \\
\hline $\mathrm{O} 3-\mathrm{V} 1-\mathrm{O} 2$ & $92.62(15)$ & $\mathrm{O} 1-\mathrm{V} 1-\mathrm{O} 2$ & $154.74(16)$ \\
\hline O6-V1-N1 & $98.64(18)$ & O3-V1-N1 & $161.95(16)$ \\
\hline O1-V1-N1 & $84.28(16)$ & $\mathrm{O} 2-\mathrm{V} 1-\mathrm{N} 1$ & $75.01(15)$ \\
\hline O6-V1-O4 & $170.84(17)$ & $\mathrm{O} 3-\mathrm{V} 1-\mathrm{O} 4$ & $75.41(14)$ \\
\hline $\mathrm{O} 1-\mathrm{V} 1-\mathrm{O} 4$ & $85.08(15)$ & $\mathrm{O} 2-\mathrm{V} 1-\mathrm{O} 4$ & $80.47(14)$ \\
\hline $\mathrm{N} 1-\mathrm{V} 1-\mathrm{O} 4$ & $89.39(14)$ & & \\
\hline \multicolumn{4}{|c|}{ 2. $\mathrm{CH}_{3} \mathrm{OH}$} \\
\hline $\mathrm{V} 1-\mathrm{O} 1$ & $1.859(2)$ & $\mathrm{V} 1-\mathrm{O} 2$ & $1.971(2)$ \\
\hline $\mathrm{V} 1-\mathrm{O} 3$ & $1.868(3)$ & $\mathrm{V} 1-\mathrm{O} 4$ & $2.153(3)$ \\
\hline V1-O6 & $1.593(3)$ & V1-N1 & $2.090(3)$ \\
\hline O6-V1-O1 & $99.44(14)$ & O6-V1-O3 & $95.72(13)$ \\
\hline $\mathrm{O} 1-\mathrm{V} 1-\mathrm{O} 3$ & $101.74(12)$ & $\mathrm{O} 6-\mathrm{V} 1-\mathrm{O} 2$ & $95.01(13)$ \\
\hline $\mathrm{O} 1-\mathrm{V} 1-\mathrm{O} 2$ & $157.06(11)$ & $\mathrm{O} 3-\mathrm{V} 1-\mathrm{O} 2$ & $94.40(11)$ \\
\hline O6-V1-N1 & $103.59(13)$ & $\mathrm{O} 1-\mathrm{V} 1-\mathrm{N} 1$ & $84.32(11)$ \\
\hline O3-V1-N1 & $158.58(12)$ & $\mathrm{O} 2-\mathrm{V} 1-\mathrm{N} 1$ & $74.98(11)$ \\
\hline O6-V1-O4 & $170.22(13)$ & $\mathrm{O} 1-\mathrm{V} 1-\mathrm{O} 4$ & $87.93(11)$ \\
\hline $\mathrm{O} 3-\mathrm{V} 1-\mathrm{O} 4$ & $76.37(10)$ & $\mathrm{O} 2-\mathrm{V} 1-\mathrm{O} 4$ & $80.09(11)$ \\
\hline $\mathrm{N} 1-\mathrm{V} 1-\mathrm{O} 4$ & $83.41(11)$ & & \\
\hline
\end{tabular}

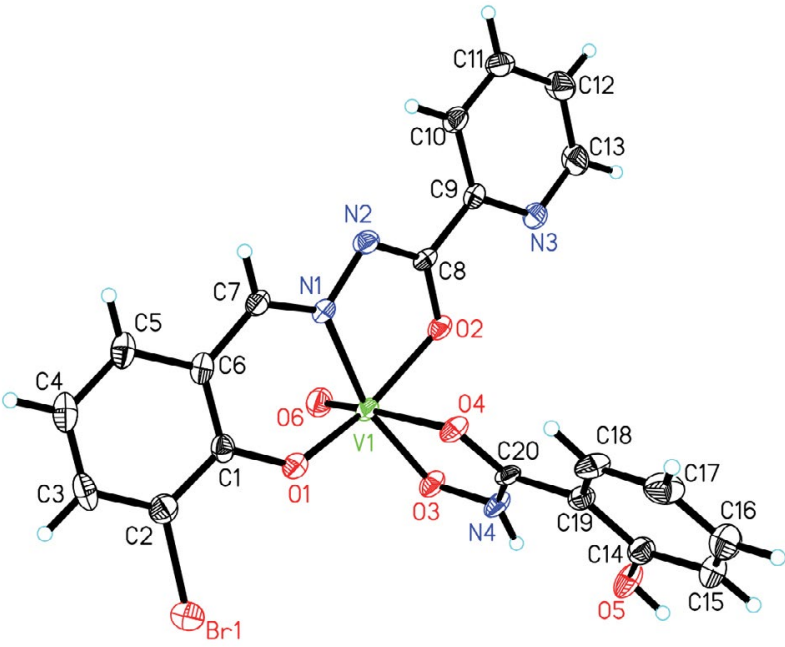

Fig. 1. Molecular structure of complex 1, showing the atom-numbering scheme. Displacement ellipsoids are drawn at the $30 \%$ probability level.

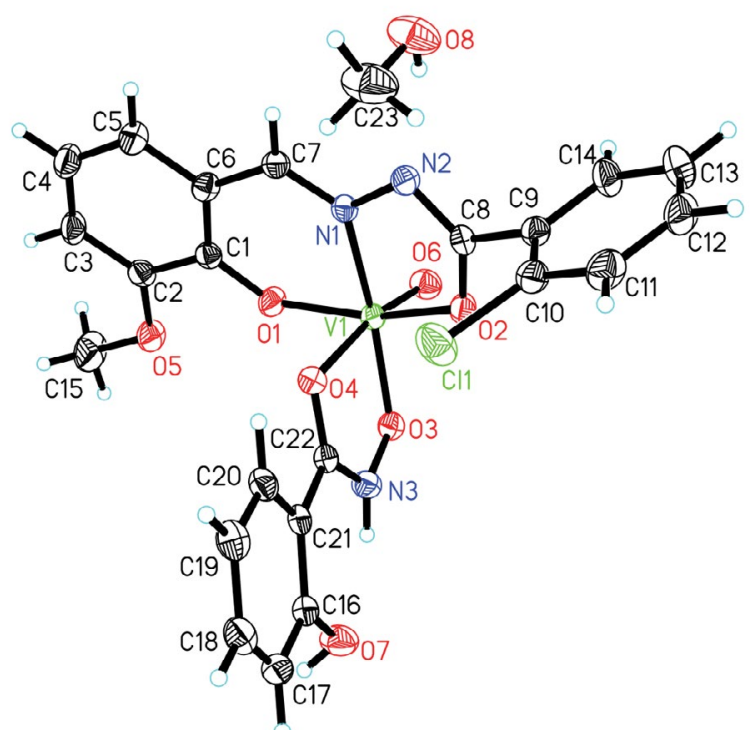

Fig. 2. Molecular structure of compound $2 \cdot \mathrm{CH}_{3} \mathrm{OH}$, showing the atom-numbering scheme. Displacement ellipsoids are drawn at the $30 \%$ probability level.

Table 3. Hydrogen bond distances $(\AA)$ and bond angles $\left(^{\circ}\right)$ for the complexes

\begin{tabular}{|c|c|c|c|c|}
\hline$D-\mathbf{H} \cdots A$ & $d(D-H)$ & $d(\mathrm{H} \cdots A)$ & $d(D \cdots A)$ & Angle $(D-H \cdots A)$ \\
\hline \multicolumn{5}{|c|}{1} \\
\hline $\mathrm{O} 5-\mathrm{H} 5 \cdots \mathrm{O} 2^{\mathrm{i}}$ & 0.82 & 2.42 & $3.051(5)$ & 134.4 \\
\hline $\mathrm{O} 5-\mathrm{H} 5 \cdots \mathrm{N} 3^{\mathrm{i}}$ & 0.82 & 2.04 & $2.780(6)$ & 150.7 \\
\hline \multicolumn{5}{|c|}{ 2. $\mathrm{CH}_{3} \mathrm{OH}$} \\
\hline $\mathrm{N} 3-\mathrm{H} 3 \cdots \mathrm{O} 5^{\mathrm{ii}}$ & $0.898(10)$ & $2.50(4)$ & $3.196(4)$ & $134(4)$ \\
\hline $\mathrm{O} 7-\mathrm{H} 7 \cdots \mathrm{O} 8^{\mathrm{iii}}$ & 0.82 & 1.84 & $2.621(4)$ & 159.8 \\
\hline $\mathrm{O} 8-\mathrm{H} 8 \cdots \mathrm{N} 2^{\mathrm{iv}}$ & 0.82 & 2.10 & $2.874(4)$ & 157.9 \\
\hline C7-H7A $\cdots$ O $^{v}$ & 0.93 & 2.53 & $3.1762(3)$ & 127 \\
\hline $\mathrm{C} 18-\mathrm{H} 18 \cdots \mathrm{O} 5^{\mathrm{vi}}$ & 0.93 & 2.58 & $3.4652(4)$ & 160 \\
\hline C19-H19...O66 vii & 0.93 & 2.56 & $3.4513(4)$ & 160 \\
\hline
\end{tabular}

Symmetry codes for i): $1-x,-y, 1-z$;ii): $-x, 1-y,-z$;iii): $-x, 1 / 2+y, 1 / 2-z$; iv): $1-x,-1 / 2+y, 1 / 2-z$; v): $1-x$, $1-y,-z ; \mathrm{vi}):-x, 2-y,-z ; \mathrm{vii}): x, 1+y, z$. 


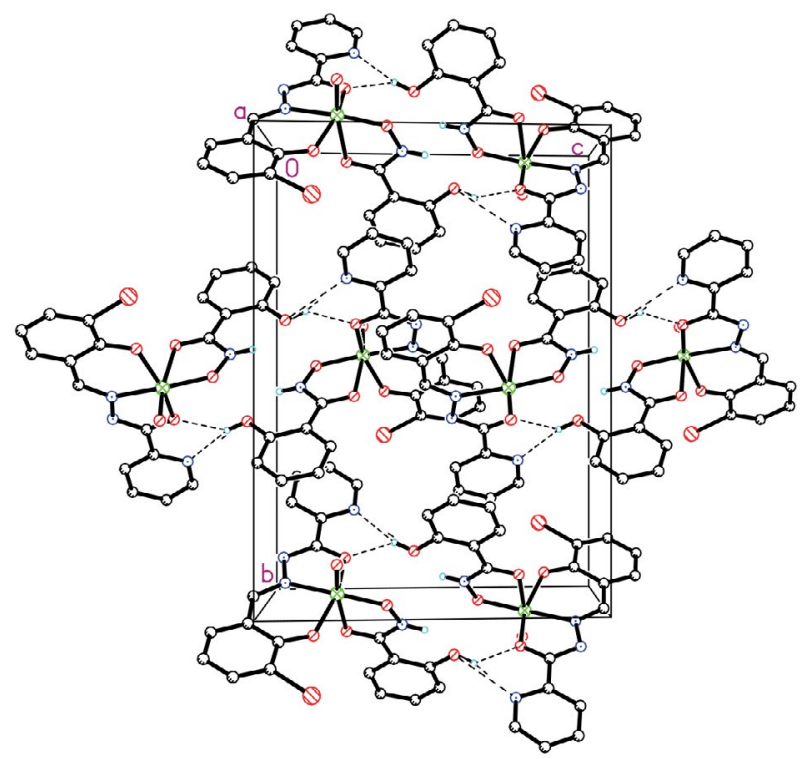

Fig. 3. Crystal packing structure of complex 1, viewed along the $a$ axis. Hydrogen bonds are shown as dashed lines.

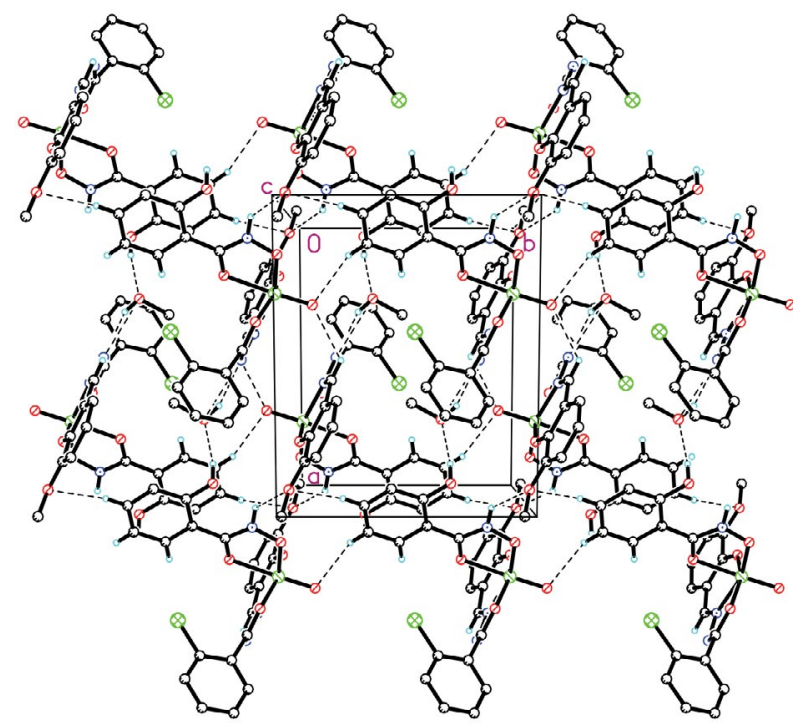

Fig. 4. Crystal packing structure of compound $2 \cdot \mathrm{CH}_{3} \mathrm{OH}$, viewed along the $c$ axis. Hydrogen bonds are shown as dashed lines.

$88.9(6)^{\circ}$ for 2 . In the crystal structures of the complexes, molecules are linked through hydrogen bonds (Table 3), to form three dimensional networks (Figs. 3 and 4).

\section{3. IR and UV-Vis Spectra of the Complexes}

The $v(\mathrm{C}=\mathrm{N})$ absorptions are observed at $1607 \mathrm{~cm}^{-1}$ for complex 1 and $1618 \mathrm{~cm}^{-1}$ for complex $2 .{ }^{13}$ The intense bands indicative of the $\mathrm{C}=\mathrm{O}$ vibrations are absent in the complexes, indicating the enolization of the hydrazone ligands. The sharp bands indicative of the $\mathrm{N}-\mathrm{H}$ vibrations are located at $3272 \mathrm{~cm}^{-1}$ for complex 1 and $3252 \mathrm{~cm}^{-1}$ for complex 2 . The weak peaks in the low wave numbers in the region $450-700 \mathrm{~cm}^{-1}$ may be attributed to $\mathrm{V}-\mathrm{O}$ and $\mathrm{V}-\mathrm{N}$ bonds in the complexes. Complexes $\mathbf{1}$ and $\mathbf{2}$ exhibit typical bands at $953 \mathrm{~cm}^{-1}$, which are assigned to the $\mathrm{V}=\mathrm{O}$ vibrations. ${ }^{14}$

The UV-Vis spectra of the complexes were recorded in $10^{-5} \mathrm{~mol} \mathrm{~L}^{-1}$ in ethanol, in the range $200-800 \mathrm{~nm}$. The weak bands centered at $326 \mathrm{~nm}$ for complex 1 and $335 \mathrm{~nm}$ for complex 2 are attributed to intramolecular charge transfer transitions from the $p_{\pi}$ orbital on the nitrogen and oxygen to the empty $d$ orbitals of the metal. ${ }^{15}$ The intense bands observed at about $275 \mathrm{~nm}$ for the complexes are assigned to intraligand $\pi-\pi^{*}$ transition. ${ }^{15}$ The bands centered at $580 \mathrm{~nm}$ for complex 1 and $570 \mathrm{~nm}$ for complex 2 are attributed to the ligand-to-metal charge transfer transitions (LMCT). ${ }^{16}$

\section{4. Antibacterial Activities}

The complexes were screened for antibacterial activities against two Gram-positive bacterial strains (B. subtilis and $S$. aureus) and two Gram-negative bacterial strains ( $E$. coli and $P$. aeruginosa) by MTT method. The $\mathrm{IC}_{50}$ values of the complexes against the bacteria are presented in Table 4 . Penicillin $\mathrm{G}$ was tested as a reference drug. Complex $\mathbf{1}$ exhibited effective activity against $B$. subtilis, and weak activity against $S$. aureus, while no activity against Gram-negative bacteria E. coli and P. aeruginosa. Complex 2 exhibited effective activity against $B$. subtilis and $S$. aureus, weak activity against $E$. coli, while no activity against $P$. aeruginosa. In general, complex 2 has stronger activity against $B$. subtilis, S. aureus and E. coli than complex $\mathbf{1}$, which might be caused by the existence of the biological active substitute group, $\mathrm{Cl}$. Both the free hydrazones $\mathrm{H}_{2} \mathrm{~L}^{1}$ and $\mathrm{H}_{2} \mathrm{~L}^{2}$, and the hydroxamic acid HL have no or very weak activities on the bacteria. $\mathrm{VO}(\mathrm{acac})_{2}$ has weak activities on B. subtilis, $S$. aureus and E. coli, and no activity on P. aeruginosa.

Table 4. Antibacterial results $\left(\mathrm{IC}_{50}, \mu \mathrm{g} \mathrm{mL} \mathrm{m}^{-1}\right)$

\begin{tabular}{|c|c|c|c|c|}
\hline \multirow[t]{2}{*}{ Compound } & \multicolumn{2}{|c|}{ Gram-positive } & \multicolumn{2}{|c|}{ Gram-negative } \\
\hline & B. subtilis & S. aureus & E. coli & P. aeruginosa \\
\hline 1 & 5.32 & 13.0 & $>50$ & $>50$ \\
\hline 2 & 3.10 & 2.56 & 21.7 & $>50$ \\
\hline $\mathrm{H}_{2} \mathrm{~L}^{1}$ & 35.6 & $>50$ & $>50$ & $>50$ \\
\hline $\mathrm{H}_{2} \mathrm{~L}^{2}$ & 22.7 & 32.9 & $>50$ & $>50$ \\
\hline $\mathrm{HL}$ & $>50$ & $>50$ & $>50$ & $>50$ \\
\hline $\mathrm{VO}(\mathrm{acac})_{2}$ & 16.7 & 25.3 & 38.2 & $>50$ \\
\hline Penicillin G & 2.35 & 0.75 & 17.5 & 17.5 \\
\hline
\end{tabular}

\section{Conclusion}

Two new oxidovanadium(V) complexes were obtained and structurally characterized. The complexes show superior antibacterial activities against $B$. subtilis, S. aureus and $E$. coli than the free ligands and $\mathrm{VO}(\mathrm{acac})_{2}$. Complex 2 
has similar activities against $B$. subtilis when compared with penicillin $\mathrm{G}$. The presence of $\mathrm{Cl}$ substitute group in the complex may enhance the antibacterial activity.

\section{Supplementary Materials}

X-ray crystallographic data for the complexes have been deposited with the Cambridge Crystallographic Data Centre (The Director, CCDC, 12 Union Road, Cambridge, CB2 1 EZ, UK; e-mail: deposit@ccdc.cam.ac.uk; http:// www.ccdc.cam.ac.uk; fax: +44-(0)1223-336033) and are available free of charge on request, quoting the deposition number CCDC 1914265 for $\mathbf{1}$, and 1914266 for 2.

\section{References}

1. (a) G. M. Chans, A. Nieto-Camacho, T. Ramirez-Apan, S. Hernandez-Ortega, C. Alvarez-Toledano, E. Gomez, Aust. J. Chem. 2016, 69, 279-290; DOI:10.1071/CH15344

(b) F. Qureshi, M. Y. Khuhawar, T. M. Jahangir, A. H. Channar, Acta Chim. Slov. 2016, 63, 113-120;

DOI:10.17344/acsi.2015.1994

(c) Y.-T. Li, J.-W. Dong, Y. Lu, Y.-T. Gu, C.-N. Shang, F.-Y. Liu, Y. Xin, C.-L. Jing, Z.-L. You, Chinese J. Inorg. Chem. 2018, 34, 1192-1198;

(d) Z. You, H. Yu, Z. Li, W. Zhai, Y. Jiang, A. Li, S. Guo, K. Li, C. Lv, C. Zhang, Inorg. Chim. Acta 2018, 480, 120-126; DOI:10.1016/j.ica.2018.05.020

(e) X.-W. Zhu, Acta Chim. Slov. 2018, 65, 939-945;

DOI:10.17344/acsi.2018.4607

(f) M. Liang, N. Sun, D.-H. Zou, Acta Chim. Slov. 2018, 65, 964-969. DOI:10.17344/acsi.2018.4625

2. J. Tian, D. Li, F. Zhai, X. Wang, R. Li, Med. Chem. Res. 2010, 19, 1162-1173. DOI:10.1007/s00044-009-9260-2

3. (a) N. Patel, A. K. Prajapati, R. N. Jadeja, R. N. Patel, S. K. Patel, V. K. Gupta, I. P. Tripathi, N. Dwivedi, Inorg. Chim. Acta 2019, 493, 20-28; DOI:10.1016/j.ica.2019.04.050

(b) T. Kolesa-Dobravc, K. Maejima, Y. Yoshikawa, A. Meden, H. Yasui, F. Perdih, New J. Chem. 2018, 42, 3619-3632;

DOI:10.1039/C7NJ04189F

(c) T. Jakusch, T. Kiss, Coord. Chem. Rev. 2017, 351, 118-126; DOI:10.1016/j.ccr.2017.04.007

(d) J.-B. Wang, L.-P. Lu, J.-Y. Liu, Y.-S. Li, Dalton Trans. 2014 , 43, 12926-12934; DOI:10.1039/C4DT01166J

(e) I. Z. Gundhla, R. S. Walmsley, V. Ugirinema, N. O. Mnonopi, E. Hosten, R. Betz, C. L. Frost, Z. R. Tshentu, J. Inorg. Biochem. 2015, 145, 11-18.

DOI:10.1016/j.jinorgbio.2014.12.019

4. (a) A. K. Srivastava, Mol. Cell. Biochem. 2000, 206, 177-182; DOI:10.1023/A:1007075204494 (b) M. Yamaguchi, H. Oishi, Y. Suketa, Res. Exp. Med. 1989, 189, 47-53; DOI:10.1007/BF01856029

(c) J. Jiang, M. Yang, Y. Gao, J. Wang, D. Li, T. Li, Chemosphere 2017, 180, 295-301.

DOI:10.1016/j.chemosphere.2017.03.116

5. (a) M. Mba, M. Pontini, S. Lovat, C. Zonta, G. Bernardinelli, P. E. Kundig, G. Licini, Inorg. Chem. 2008, 47, 8616-8618; DOI:10.1021/ic8015113

(b) X. A. Zhang, W. D. Woggon, J. Am. Chem. Soc. 2005, 127, 14138-14139; DOI:10.1021/ja053209r

(c) X. A. Zhang, M. Meuwly, W. D. Woggon, J. Inorg. Biochem. 2004, 98, 1967-1970. DOI:10.1016/j.jinorgbio.2004.07.013

6. (a) J. Farzanfar, K. Ghasemi, A. R. Rezvani, H. S. Delarami, A. Ebrahimi, H. Hosseinpoor, A. Eskandari, H. A. Rudbari, G. Bruno, J. Inorg. Biochem. 2015, 147, 54-64;

DOI:10.1016/j.jinorgbio.2015.02.007

(b) V. Pawar, S. Joshi, V. Uma, Asian J. Chem. 2013, 25, $1497-$ 1500; (c) I. Sheikhshoaie, S. Y. Ebrahimipour, N. Lotfi, J. T. Mague, M. Khaleghi, Inorg. Chim. Acta 2016, 442, 151-157. DOI:10.1016/j.ica.2015.11.026

7. (a) M. He, Q.-Z. Jiao, X.-F. Chen, J. Li, J. Chen, G.-H. Sheng, Z.-L. You, Chin. J. Inorg. Chem. 2015, 31, 1590-1596;

(b) J.-Q. Ren, Q.-Z. Jiao, Y.-N. Wang, F.-Y. Xu, X.-S. Cheng, Z.-L. You, Chin. J. Inorg. Chem. 2014, 30, 640-648;

(c) X. L. Zhao, X. F. Chen, J. Li, J. Chen, G. Sheng, F. Niu, D. Qu, Y. Huo, H. Zhu, Z. You, Polyhedron 2015, 97, 268-272.

DOI:10.1016/j.poly.2015.07.012

8. H. Y. Qian, Russ. J. Coord. Chem. 2017, 43, 780-786. DOI:10.1134/S1070328417110070

9. SMART (version 5. 624) and SAINT (version 6.04), Programs Using the Windows NT System, Madison (WI, USA): Bruker AXS Inc. 2001.

10. G. M. Sheldrick, SADABS, Program for Empirical Absorption Correction of Area Detector, Göttingen (Germany): Univ. of Göttingen 1996.

11. G. M. Sheldrick, Acta Crystallogr. A 2008, 64, 112-122. DOI: $10.1107 /$ S0108767307043930

12. (a) D. Qu, F. Niu, X. Zhao, K.-X. Yan, Y.-T. Ye, J. Wang, M. Zhang, Z. You, Bioorg. Med. Chem. 2015, 23, 1944-1949; DOI:10.1016/j.bmc.2015.03.036

(b) L.-X. Li, Y. Sun, Q. Xie, Y.-B. Sun, K.-H. Li, W. Li, Z.-L. You, Chin. J. Inorg. Chem. 2016, 32, 369-376.

13. Z.-L. You, D.-M. Xian, M. Zhang, CrystEngComm 2012, 14, 7133-7136. DOI:10.1039/c2ce26201k

14. N. R. Sangeetha, V. Kavita, S. Wocadlo, A. K. Powell, S. Pal, J. Coord. Chem. 2000, 51, 55-66.

DOI: $10.1080 / 00958970008047078$

15. G. Asgedom, A. Sreedhara, J. Kivikoski, E. Kolehmainen, C. P. Rao, J. Chem. Soc. Dalton Trans. 1996, 1, 93-97.

DOI:10.1039/dt9960000093

16. A. Sarkar, S. Pal, Polyhedron 2006, 25, 1689-1694. DOI:10.1016/j.poly.2005.11.009 


\section{Povzetek}

Sintetizirali smo dva nova oksidovanadijeva(V) kompleksa, $\left[\mathrm{VOL}^{1} \mathrm{~L}\right](\mathbf{1})$ in $\left[\mathrm{VOL}^{2} \mathrm{~L}\right] \cdot \mathrm{CH}_{3} \mathrm{OH}\left(\mathbf{2} \cdot \mathrm{CH}_{3} \mathrm{OH}\right)$, kjer sta $\mathrm{L}^{1}$ in $\mathrm{L}^{2}$ dianionski obliki $N^{\prime}$-(3-bromo-2-hidroksibenziliden)pikolinohidrazida $\left(\mathrm{H}_{2} \mathrm{~L}^{1}\right)$ in 2-kloro- $N^{\prime}$-(2-hidroksi-3-metoksibenziliden)benzohidrazida $\left(\mathrm{H}_{2} \mathrm{~L}^{2}\right)$ ter L monoanionska oblika 2-hidroksibenzohidroksamske kisline (HL). Kompleksa smo okarakterizirali z elementno analizo, infrardečo in elektronsko spektroskopijo. Strukturi kompleksov sta bili potrjeni tudi z monokristalno rentgensko analizo. V kompleksu je V atom koordiniran oktaedrično. Hidrazonski ligand se koordinira na $\mathrm{V}$ atom preko fenolatnega $\mathrm{O}$, iminskega $\mathrm{N}$ in enolatnega $\mathrm{O}$ atoma. Hidroksamatni ligand se koordinira na $\mathrm{V}$ atom preko karbonilnega in hidroksilnega $\mathrm{O}$ atoma. Kompleksa izražata antibakterijsko aktivnost proti B. subtilis, S. aureus in E. coli. Prisotnost $\mathrm{Cl}$ skupine na ligandu verjetno ojača antibakterijsko aktivnost. 